\title{
ANALISIS FAKTOR-FAKTOR YANG MEMPENGARUHI MINAT NASABAH MENABUNG DI BANK JATENG SYARIAH
}

\author{
Akhmad Darmawan, S.E.,M.si ${ }^{(1)}$, Ninik Dewi Indahsari ${ }^{(2)}$ \\ Sri Rejeki ${ }^{(3)}$, Muhammad Rizqie Aris ${ }^{(4)}$, Roqi Yasin ${ }^{(5)}$ \\ Program Studi Manajemen Fakultas Ekonomi dan Bisnis \\ Universitas Muhammadiyah Purwokerto ${ }^{1,2}$ \\ Program Studi Ekonomi Syariah Pasca Sarjana IAIN Purwokerto $3,4,5$ \\ akhmaddarmawan@ump.ac.id,ninikdewi18@gmail.com \\ bujeki19@gmail.com, rizqie.aris@gmail.com, yasinroqi@gmail.com
}

\begin{abstract}
This study aims to determine the factors that influence customers' interest in saving at Jateng Syariah Bank. This study uses quantitative research methods, non-probability sampling techniques can be obtained through purposive sampling. The population in this study was a customer at Purwokerto Syariah Bank Jateng and was 17 years old. Samples in this study were 170 respondents. The research method used in this study is validity test, reliability test, classic assumption test, multiple regression analysis, coefficient of determination, $F$ test, $t$ test. Location has no significant negative effect on saving interest, Service has a significant positive effect on saving interest, Knowledge has a significant positive effect on saving interest, Promotion has no significant positive effect on saving interest, Product has no significant positive effect on saving interest, Price has no significant positive effect on interest save.
\end{abstract}

Keywords: Location, Service, Knowledge, Promotion, Product, Price, Interest in saving

\section{PENDAHULUAN}

Tingkat minat menabung nasabah pada bank syariah dapat diukur melalui indeks inklusi, kebijakan keuangan inklusif adalah suatu bentuk pendalaman layanan keuangan (financial service deepening) yang ditujukan kepada masyarakat in the bottom of the pyramid untuk memanfaatkan produk dan jasa keuangan formal seperti sarana menyimpan uang yang aman (keeping), transfer, menabung maupun pinjaman dan asuransi. Hal ini dilakukan tidak saja menyediakan produk dengan cara yang sesuai tapi dikombinasikan dengan berbagai aspek.Indeks Keuangan Inklusif (IKI) adalah salah satu cara alternatif untuk pengukuran keuangan inklusif yang menggunakan indeks multidimensional berdasarkan data makroekonomi, terutama pada jangkauan layanan sektor perbankan. Pengukuran IKI pada dasarnya merupakan upaya yang dilakukan Bank Indonesia untuk mengkombinasikan berbagai indikator sektor perbankan, sehingga pada akhirnya IKI dapat menggabungkan beberapa informasi mengenai berbagai dimensi dari sebuah sistem keuangan yang inklusif, yaitu akses (access), penggunaan (usage) dan kualitas (quality) dari layanan perbankan.(BI)

Menurut hasil Survei nasional tahun 2013 tingkat indeks inklusi keuangan pada tahun 2013 sebesar 59,74\%. Sedangkan indeks inklusi keuangan pada tahun 20132016 mengalami peningkatan yaitu sebesar $8.08 \%$, pada tahun 2013 tingkat indeks inklusi keuangan sebesar $59.74 \%$ dan pada tahun 2016 tingkat indeks inklusi keuangan sebesar $67.82 \%$. Berbeda dengan tingkat indeks inklusi keuangan pada tahun 2016 yaitu sebesar $67.82 \%$, tingkat indeks inklusi keuangan syariah pada tahun 2016 yaitu sebesar $11.06 \%$. Inklusi keuangan sektoral syariah pada perbankan menunjukan tingkat inklusi sebesar 9,61\%. (OJK, 2017) 
Salah satu yang mempengaruhi minat menabung adalah lokasi atau tempat. Lokasi dalam penelitian Syaibuan (2018) menyebutkan bahwa lokasi berpengaruh positif signifikan terhadap minat menabung sejalan dengan penelitian Abdul latief (2018) yang menyatakan bahwa lokasi berpengaruh positif sugnifikan terhadap minat.

Dalam penelitian ini juga menggunakan variabel pelayanan. Pelayanan dalam penelitian Ainun Mardiah, Agung, Junaidi (2017) menyatakan bahwa pelayanan berpengaruh positif signifikan terhadap minat menabung sejalan dengan penelitian Syaribuan (2018) dan Sisca Damayanti (2018) yang menyatakan bahwa pelayanan berpengaruh positif signifikan terhadap minat menabung. Selain variabel lokasi dan pelayanan,pengetahuan juga berpengaruh positif signifikan terhadap minat menabung. Pengetahuan dalam penelitian Yuliana (2018) menyatakan bahwa pengetahuan berpengaruh positif signifikan terhadap minat menabung sejalan dengan penelitian Pudji (2018) yang menyatakan bahwa pengetahuan berpengaruh positif signifikan terhadap minat menabung.

Selain variabel lokasi,pelayanan dan pengetahuan, promosi juga berpengaruh positif signifikan terhadap minat menabung sejalan dengan penelitian yang dilakukan Roni Andespa (2017) yang menyatakan bahwa promosi berpengaruh positif signifikan terhadap minat menabung, sejalan dengan penelitian Syaribuan (2018) yang menyatakan bahwa promosi berpengaruh positif signifikan terhadap minat menabung.

Selain variabel lokasi, pelayanan, pengetahuan, promosi, produk juga berpengaruh positif signifikan terhadap minat menabung. Sejalan dengan penelitian Roni Andepa (2017) yang menyatakan bahwa produk berpengaruh positif signifikan terhadap minat menabung, sejalan dengan penelitian yang dilakukan Ainun,Agung, Junaidi yang menyatakan bahwa produk berpengaruh positif signifikan terhadap minat menabung. Sejalan juga dengan penelitian Syaribuan (2018) yang menyatakan bahwa produk berpengaruh positif signifikan terhadap minat menabung.

Selain variabel lokasi, pelayanan, pengetahuan, promosi dan produk, variabel harga juga berpengaruh positif signifikan terhadap minat menabung, sejalan dengan penelitian Roni Andepa (2018) yang menyatakan bahwa harga berpengaruh positif signifikan terhadap minat menabung, Sejalan juga dengan penelitian Dr. Ren (2016) yang menyatakan bahwa harga berpengaruh positif signifikan terhadap minat menabung, sejalan dengan penelitian Jonathan Herdioko (2017) yang menyatakan bahwa harga berpengaruh positif signifikan terhadap minat menabung, Sejalan juga dengan penelitian Dr. Ren (2016) yang menyatakan bahwa harga berpengaruh positif signifikan terhadap minat menabung dan penelitian adul latief yang menyatakan bahwa harga berpengaruh positif signifikan terhadap minat menabung.

Sehingga tujuan dari penelitian ini adalah Untuk menguji pengaruh lokasi terhadap minat nasabah menabung di Bank Jateng Syariah.Untuk menguji pengaruh pelayanan terhadap minat nasabah menabung di Bank Jateng Syariah, Untuk menguji pengaruh pengetahuan terhadap minat nasabah menabung di Bank Jateng Syariah, Untuk menguji pengaruh promosi terhadap minat nasabah menabung di Bank Jateng Syariah, Untuk menguji pengaruh produk terhadap minat nasabah menabung di Bank Jateng Syariah, Untuk menguji pengaruh harga terhadap minat nasabah menabung di Bank Jateng Syariah.

\section{TINJAUAN PUSTAKA}

Bank Islam atau selanjutnya disebut dengan Bank Syariah adalah bank yang beroperasi dengan tidak mengandalkan pada bunga. Bank Islam atau biasa disebut dengan Bank Tanpa Bunga, adalah lembaga keuangan/perbankan yang operasional dan produknya dikembangkan berlandaskan pada Al-Qur'an dan Hadis Nabi Saw. Antonio dan Perwataatmadja membedakan menjadi dua pengertian, yaitu Bank Islam dan Bank yang beroperasi dengan prinsip syariah islam. Bank 
Islam adalah bank yang beroperasi sesuai dengan prinsip-prinsip syariah islam. Sementara bank yang beroperasi sesuai prinsip syariah islam adalah bank yang dalam beroperasinya itu mengikuti ketentuanketentuan syariah islam, khususnya yang menyangkut tata cara bermuamalat secara islam. (Muhammad, 2014; 2), (kasmir, 2014)

Peningkatan minat menabung di pengaruhi oleh adanya faktor lokasi. Lokasi adalah tempat secara fisik dalam arti kantor bank dan saluran bagi nasabah untuk mengakses berbagai produk dan jasa perbankan. Studi yang dilakukan Fema dan McKisey \& Company di Eropa serta Biannuci (2015) tentang tantangan penyampaian jasa perbankan multi saluran menunjukan bahwa meskipun teknologi internet berkembang, namun peran kantor bank sebagai tempat nasabah untuk mengakses layanan produk dan jasa berkembang masih diperlukan. Sesuai dengan fungsinya sebagai saluran distribusi, kantor bankharus dapat menjalankan fungsifungsi antara lain informasi, promosi, kontak, penyesuaian, dan negosiasi. (Suryani Tatik,2017), (Syaribuan, 2018), (Abdul Latief, 2018).

Selanjutnya variabel pelayanan, Pelayanan Dalam Kamus Besar Bahasa Indonesia dijelaskan bahwa pelayanan sebagai usaha melayani kebutuhan orang lain. Sedangkan dalam definisi strategis dinyatakan bahwa kualitas adalah segala sesuatu yang mampu memnuhi keinginan dan kebutuhanpelanggan (meeting the needs ofcustomers). Pelayanan adalah bentuk pemberian layanan yang diberikan oleh produsen baik terhadap pengguna barang diproduk maupun jasa yang ditawarkan oleh Bank Syariah Kota Kualasimpang. Suatu pelayanan yang baik akan mendorong seseorang untuk mengunakan jasa maupun produk yang ditawarkan, pelayanan yang baik menunjukkan sesuatu yang sudah sesuai dengan keinginan dan mampu memenuhi kebutuhan nasabah (Ainun Mardiah , Agung Pradhana Putra, Junaidi, 2017). Pelayanan merupakan faktor yang penting dalam sebuah industri perbankan, karena perbankan merupakan usaha yang menjual jasa yang mengutamakan service dan keramahan dalam melayani calon nasabah.Pelayanan sendiri merupakan perilaku produsen dalam rangka memenuhi kebutuhan dan keinginan konsumen demi tercapainya kepuasan pada konsumen itu sendiri. Dimana perilaku tersebut dapat terjadi pada saat, sebelum dan sesudah terjadinya transaksi. Pada umumnya pelayanan yang bertaraf tinggi akan menghasilkan kepuasan yang tinggi serta pembelian ulang yang lebih sering. (Damayanti, 2017; 19) (Ainun Mardiah, Agung, Junaidi, 2017), (Syaribuan, 2018)

Selanjutnya variabel Promosi, Promosi merupakan salah satu cara bank untuk menarik dan mempertahankan masyarakat agar tetap menabung pada bank tersebut Namun kegiatan promosi yang dilakukan bank juga bisa mengurangi minat masyarakat untuk menabung pada bank tersebut apabila dilakukan dengan tujuan dan penyampaian yang tidak tepat bahkan berlebihan. Oleh karena itu, bank harus dapat memanfaatkan dengan baik dan benar media promosi seperti iklan pada media cetak atau elektronik, promosi langsung dan lain sebagainya. Dalam hal ini bank harus mengetahui media promosi yang paling mudah dimengerti dan sering dijumpai oleh masyarakat (Daniel \& Anas, 2017; 89).Kegiatan promosi bukan saja sebagai alat komunikasi antara perusahaan dan konsumen, melainkan juga sebagai alat untuk memengaruhi konsumen dalam kegiatan pembelian atau penggunaan jasa sesuai dengan keinginan dan kebutuhannya.Hal ini dilakukan dengan menggunakan alat-alat promosi (Rambat, 2017), (lupiyoadi, 2017).

Media Promosi dapat berupa media cetak seperti koran, media elektronik seperti televisi, dan dapat juga berupa informasi yang disampaikan melalui internet. Dalam kegiatan promosi biasanya bank melakukan empat sarana promosi, salah satunya yaitu: periklanan (advertising). Periklanan merupakan salah satu bentuk dari komunikasi impersonal (impersonal communication) yang digunakan oleh perusahaan dalam 
mengomunikasikan produknya, baik barang maupun jasa. Peranan iklan dalam pemasaran jasa adalah untuk membangun kesadaran (awareness) terhadap keberadaan jasa yang ditawarkan, menambah pengetahuan konsumen tentang jasa yang ditawarkan, membujuk calon konsumen untuk membeli atau menggunakan jasa tersebut, dan membedakan diri perusahaan satu dengan perusahaan lain yang mendukung penentuan posisi jasa (Lupiyoadi, 2017), (kotler keller, 2009).

Variabel produk, Menurut Tatik Suryani, 2017 pemahaman terhadap produk dan jasa perbankan serta karakteristiknya sangat penting bagi pemasar agar dapat menawarkan produk tersebut secara tepat. Seperti hal nya jasa yang lain produk dan jasa perbankan bersifat: tidak berwujud, tidak dapat dipisahkan, beraneka ragam, tidak mudah rusak, dan kepemilikannya tidak dapat dipindahkan. Terdapat berbagai macam produk dan jasa perbankan, baik di perbankan konvensional maupun perbankan syariah. Pada perbankan konvensional dari berbagai jenis produk dan jasa tersebut dapat dikelompokkan menjadi 3, yaitu produk simpanan yang terdiri dari tabungan, deposito, dan rekening giro.Produk pinjaman terdiri dari kredit konsumtif dan kredit komersial dan jasa perbankan yang meliputi safe deposit box, transfer, inkaso, bank draf, dan cek wisata.(Tatik, 2017). Secara konseptual, produk adalah pemahaman subyektif produsen atas sesuatu yang bisa ditawarkan sebagai usaha untuk mencapai tujuan organisasai melalui pemenuhan kebutuhan dan keinginann konsumen, sesuai dengan kompetensi dan kapasitas organisasi serta daya beli pasar, selain itu produk dapat pula di definisikan sebagai persepsi konsumen yang di jabarkan oleh produsen melalui hasil produksi atau operasinya. Menurut Tjiptono Fandy, (2015:231-232). Suryani Tatik, (2017:124-130) dan undang-undang nomor 21 tahun 2008 tentang perbankan menyatakan bahwa Produk dan jasa bank konvensional secara garis besar dapat dikelompokan menjadi dua jenis, yaitu: produk simpanan dan produk pinjaman. Menurut Tjiptono Fandy, (2015:231-232). Suryani Tatik, (2017:124-130).

Variabel harga, Harga adalah faktor utama yang harus ditentukan sebelum suatu produk di luncurkan ke pasar sasaran. Harga produk juga salah satu faktor penentu bagi permintaan pasar yang secara otomatis akan mempengaruhi volume penjualan. Jika harga produk tidak dapat di jangkau konsumen, maka target penjualan yang telah ditetapkan tidak tercapai. (Andespa, 2017). Menurut Suryani Tatik, (2017:138-141) pada umunya, harga diartikan sebagai sejumlah uang yang di bayarkan oleh konsumen untuk memperoleh produk yang dibayarkan oleh konsumen untuk memperoleh produk yang diinginkan. Dalam konteks perbankan harga merupakan sejumlah uang yang dibayarkan oleh nasabah kepada Bank agar bisa memanfaatkan produk atau jasa perbankan (Andespa, 2017), (Suryani Tatik, (2017:138-141).

\section{METODE PENELITIAN}

Penelitian ini menggunakan jenis penelitian kuantitatif (penelitian survai). Metode penelitian survey adalah metode penelitian kuantitatif yang digunakan untuk mendapatkan data yang terjadi pada masa lampau atau saat ini (sugiyono, 2018:81). Pendekatan kuantitatif memusatkan perhatian pada gejala-gejala yang mempunyai karakteristik tertentu di dalam kehidupan manusia yang dinamakan sebagai variabel. Dalam pendekatan kuantitatif hakikat hubungan di antara variabel-variabel dianalisis dengan menggunakan teori yang objektif (sujarweni, 2015:39). Populasi dalam penelitian ini adalah para nasabah yang berminat menabung di bank syariah. Peneliti tidak dapat mengetahui secara jelas berapa banyak nasabah yang menabung di bank jateng syariah, oleh karena itu penelitian ini dilakukan secara sampling. Teknik pengambilan sampel menggunakan metode Nonprobability Sampling (Sugiyono, 2018) adalah teknik pengambilan sampel yang tidak member peluang atau kesempatan sama bagi setiap unsur atau anggota populasi untuk 
dipilih menjadi sample, sedangkan teknik pengambilan data menggunakan Purposive sampling adalah teknik penentuan sampel dengan pertimbangan tertentu (Sugiyono, 2018). Diperoleh sampel dari penelitian ini adalah 170 sampel

Metode Analisis Data menggunakan Statistik Deskripstif, Uji Asumsi Klasik yang terdiri dari Uji Normalitas, Uji Multikolonieritas, Uji Heteroskedastisitas, dan untuk uji hipotesis menggunakan Analisis Regresi Berganda, Uji Kecocokan model dengan Koefisien Determinasi (R2), Uji F dan Uji t.

\section{HASIL}

\section{Statistik Deskriptif}

Indeks lokasi yang diukur dengan 3 item pernyataan diperoleh rata-rata sebesar 3,38. Artinya lokasi Bank Jateng Syariah sudah baik. Hal ini berarti lokasi Bank Jateng Syariah mudah dijangkau. Indeks pelayanan diukur dengan 22 item pernyataan diperoleh rata-rata sebesar 3,40. Pelayanan yang diperoleh nasabah di Bank Jateng Syariah sudah cukup baik. Indeks pengetahuan yang diukur dengan 3 pernyataan diperoleh ratarata sebesar 3,71, Pengetahuan yang diperoleh oleh para nasabah di Bank Jateng Syariah sudah cukup baik. Indeks Promosi yang diukur dengan 4 pernyataan diperoleh ratarata sebesar 3,81 yang berarti promosi yang dilakukan oleh Bank Jateng Syariah sudah cukup baik. Indeks produk yang diukur dengan 4 pernyatan diperoleh rata-rata sebesar 3,52 yang berarti produk yang diberikan oleh Bank Jateng Syariah sudah cukup baik. Indeks harga yang diukur dengan 3 item pernyataan diperoleh rata-rata sebesar 3,76 , yang berarti harga yang ditawarkan oleh Bank Jateng Syaria sudah cukup menarik nasabah untuk menabun di Bank Jateng Syariah. Indeks minat menabung yang diukur dengan 4 item pernyataan diperoleh rata-rata sebesar 3,74, yang berarti tingkat minat menabung di Bank Jateng Syariah sudah cukup baik.

\section{Uji Asumsi Klasik}

Dari hasil Uji asumsi klasik yang terdiri dari Uji Normalitas, Uji Multikolonieritas, Uji Heteroskedastisitas, yang telah dilakukan dapat disimpulkan bahwa variabel yang digunakan dalam penelitian ini seperti lokasi, pelayanan, pengetahuan, promosi, produk, harga dan minat menabung terbebas dari Uji Asumsi Klasik.

\section{Analisis Regresi Berganda}

Hasil pengujian Regresi Berganda menghasilkan persamaan sebagai berikut:

$$
\begin{aligned}
Y= & \alpha+\beta_{1} X_{1}+\beta_{2} X_{2}+\beta_{3} X_{3+} \beta_{4} X_{4}+\beta_{5} X_{5} \\
& +\beta_{6} X_{6}+e \\
= & -0,883-0,008 X_{1}+0,951 X_{2}+0,258 X_{3} \\
& +0,044 X_{4}+0,028 X_{5}+0,059 X_{6}+e
\end{aligned}
$$

Keterangan:

$\alpha=$ Nilai konstanta $(\alpha)$ menunjukan nilai negative pada konstanta yaitu $-0,883$ yang menyatakan lokasi, pelayanan, pengetahuan, promosi, produk, dan harga bernilai 0 maka minat menabung akan bernilai negatif.

$\beta_{1}=$ Nilai koefisien regresi variabel lokasi menunjukkan nilai $-0,008$ yang berarti setiap peningkatan variabel lokasi sebesar satu satuan maka minat menabung nasabah menurun 0,008 dengan asumsi variabel lainnya.

$\mathrm{B}_{2}=$ Nilai koefisien regresi variabel pelayanan menunjukkan nilai positif sebesar 0,951 yang menyatakan bahwa setiap peningkatan pelayanan sebesar satu satuan maka menyebabkan minat menabung nasabah meningkat sebesar 0,951 satuan dengan asumsi variabel lain tetap.

$\mathrm{B}_{3}=$ Nilai koefisien regresi variabel pengetahuan menunjukkan nilai positif sebesar 0,258 yang menyatakan bahwa setiap peningkatan pengetahuan sebesar satu satuan maka menyebabkan minat menabung nasabah meningkat sebesar 0,258 satuan denga asumsi variabel lain tetap.

$\mathrm{B}_{4}=$ Nilai koefisien regresi variabel promosi menunjukkan nilai positif sebesar 0,044 yang menyatakan bahwa setiap 
peningkatan promosi sebesar satu satuan maka menyebabkan minat menabung nasabah meningkat sebesar 0,258 satuan dengan asumsi variabel lain tetap.

$\mathrm{B}_{5}=$ Nilai koefisien regresi variabel produk menunjukkan nilai positif sebesar 0,028 yang menyatakan bahwa setiap peningkatan produk sebesar satu satuan maka menyebabkan minat menabung nasabah meningkat sebesar 0,028 satuan dengan asumsi variabel lain tetap.

$\mathrm{B}_{6}=$ Nilai koefisien regresi variabel harga menunjukkan nilai positif sebesar 0,059 yang menyatakan bahwa setiap peningkatan harga sebesar satu satuan maka menyebabkan minat menabung nasabah meningkat sebesar 0,059 satuan dengan asumsi variabel lain tetap.

$\mathrm{e}=$ error

\section{Koefisien Detreminasi (R2)}

Sedangkan untuk pengujian Koefisien determinasi pada tabel 4.20 menunjukan nilai Adjusted $r$ Square sebesar 0,862 menunjukan bahwa variabel independen yang terdiri dari lokasi, pelayanan, pengetahuan, promosi, produk, dan harga dalam menjelaskan variabel minat menabung sebesar $86,2 \%$ dan sisanya $13,8 \%$ di jelaskan oleh variabel lainnya yang tidak termasuk kedalam model penelitian ini.

\section{UJI t}

Berdasarkan uji yang telah dilakukan menunjukkan bahwa lokasi berpengaruh negative tidak signifikan terhadap minat menabung. Diperoleh nilai nilai signifikansi sebesar 0,790>0,05 maka Ho diterima dan Ha ditolak, dengan $\mathrm{t}$ hitung $<\mathrm{t}$ tabel yaitu $0,267<1,65426$. Pelayanan berpengaruh positif signifikan terhadap minat menabung. Diperoleh nilai signifikansi sebesar 0,000 sangat kurang dari 0,05 maka Ho ditolak Ha diterima, dengan $\mathrm{t}$ hitung $>\mathrm{t}$ tabel yaitu 7,023 $>1,65426$. Pengetahuan berpengaruh positif signifikan terhadap minat menabung. Diperoleh nilai signifikansi sebesar 0,002 kurang dari 0,05 maka Ho ditolak $\mathrm{Ha}$ diterima, dengan $\mathrm{t}$ hitung $>\mathrm{t}$ tabel yaitu 3,171 $>1,65426$. Promosi berpengaruh positif tidak signifikan terhadap minat menabung. Diperoleh nilai signifikansi sebesar 0,549 lebih besar dari dari 0,05 maka Ho diterima Ha ditolak, dengan $\mathrm{t}$ hitung $>\mathrm{t}$ tabel yaitu $0,601<1,65426$. Produk berpengaruh positif tidak signifikan terhadap minat menabung. Diperoleh nilai signifikansi sebesar 0,393 lebih besar dari dari 0,05 maka Ho diterima Ha ditolak, dengan $\mathrm{t}$ hitung $>\mathrm{t}$ tabel yaitu $0,549<1,65426$. Harga berpengaruh positif tidak signifikan terhadap minat menabung. Diperoleh nilai signifikansi sebesar 0,402 lebih besar dari dari 0,05 maka Ho diterima Ha ditolak, dengan $\mathrm{t}$ hitung $>\mathrm{t}$ tabel yaitu $0,840<1,65426$.

\section{PEMBAHASAN}

\section{a. Pengaruh lokasi terhadap minat menabung.}

Hasil uji regresi pengaruh lokasi terhadap minat menabung menunjukkan bahwa variabel lokasi berpengaruh negatif tidak signifikan pada variabel minat menabung di bank jateng syariah. Hasil ini menunjukkan lokasi tidak mempengaruhi minat nasabah untuk menabung, lokasi Bank Jateng Syariah yang berada di dekat jalan raya dan mudah dijangkau tidak berpengaruh terhadap minat nasabah untuk menabung karena cukup banyak nasabah Bank Jateng Syariah yang bertempat tinggal jauh dari lokasi Bank Jateng Syariah sehingga lokasi bukan faktor yang membuat nasabah ber minat menabung di bank jateng syariah. Hasil analisis ini sesuai dengan hasil penelitian yang telah dilakukan oleh Riries (2015) yang menyatakan bahwa lokasi tidak berpengaruh terhadap minat menabung. Hasil penelitian ini menolak hasil penelitian yang dilakukan oleh Andespa (2017) yang menyatakan bahwa lokasi berpengaruh positif signifikan terhadap minat menabung. Hasil penelitian Syaribulan (2018) menyatakan bahwa lokasi berpengaruh 
positif signifikan terhadap minat menabung.

b. Pengaruh Pelayanan terhadap minat menabung.

Hasil uji regresi pengaruh pelayanan terhadap minat menabung di bank jateng syariah menyatakan bahwa pelayanan berpengaruh positif signifikan terhadap minat menabung. Hasil penelitian menunjukkan bahwa pelayanan mempengaruhi minat nasabah menabung di bank jateng syariah, selain itu Bank Jateng Syariah juga telah mampu memberikan pelayanan yang baik terhadap nasabah, sehingga nasabah berkeinginan untuk melakukan transaksi dan menabung di bank jateng syaria. Dengan ini dapat dilihat jika pegawai bank sudah dapat melayani nasabah sesuai dengan standar operasional perusahaan, peraturan, dan prosedur yang berlaku. Hasil penelitian ini sejalan penelitian Syaribulan (2018) menyatakan bahwa pelayanan mempunyai pengaruh positif signifikan terhadap minat menabung. Hasil penelitian menunjukkan bahwa pelayanan mempengaruhi minat nasabah menabung di bank jateng syariah. Hal tersebut juga di dukung oleh penelitian (sisca damayanti , 2017) yang menyatakan bahwa pelayanan memiliki pengaruh positif dan signifikan terhadap minat menabung.

\section{c. Pengaruh Pengetahuan terhadap minat menabung}

Hasil uji regresi pengaruh pengetahuan terhadap minat menabung menyatakan bahwa pengeahuan berpengaruh positif signifikan terhadap minat menabung nasabah di bank jateng syariah. Menurut Dayyan, Riza, Ridwan (2017) Pengetahuan nasabah mengenai bank syariah yang berbeda dengan bank konvensional menjadi daya tarik tersendiri bagi nasabah untuk menabung di bank syariah. Hasil penelitian ini menunjukkan bahwa pengetahuan nasabah mengenai Bank Jateng Syariah juga dapat meningkatkan minat nasabah agar menabung di Bank Jateng Syariah. Hasil penelitian ini didukung oleh hasil penelitian yang dilakukan. Hasil penelitian ini juga didukung oleh hasil penelitian Yuliana (2018) menyatakan bahwa pengetahuan berpengaruh positif dan signifikan terhadap minat menabung.

\section{d. Pengaruh Promosi terhadap minat menabung.}

Hasil uji regresi pengaruh promosi terhadap minat menabung menyatakan bahwa promosi berpengaruh positif tidak signifikan terhadap minat menabung. Hasil penelitian ini mennjukkan bahwa promosi Bank Jateng Syariah tidak terlalu mempengaruhi minat nasabah untuk menabung di bank jateng syariah. Hasil penelitian ini didukung oleh penelitian yang dilakukan oleh Mawardi (2018) yang menyatakan bahwa promosi berpengaruh positif tidak signifikan terhadap minat menabung. Namun Hasil penelitian menolak penelitian yang dilakukan oleh Daniel Ortega, Anas Alhifni (2017) yang menyatakan bahwa promosi berpengaruh positif signifikan terhadap minat menabung. Hasil penelitian ini juga menolak penelitian yang dilakukan oleh Syaribulan (2018) yang menyatakan bahwa promosi berpengaruh positif signifikan terhadap minat menabung.

\section{e. Pengaruh Produk terhadap minat menabung.}

Hasil uji regresi pengaruh produk terhadap minat menabung menyatakan bahwa variabel produk berpengaruh positif tidak signifikan terhadap minat menabung. Menurut Ainun, Agung, Junaidi (2017) Produk tidak terlalu berpengaruh terhadap minat nasabah menabung di bank syariah karena 
promosi tentang produk yang dikeluarkan oleh bank syariah kurang di gencarkan sehingga nasabah belum mengetahui mengenai produk produk yang ada di bank syariah. Produk tidak terlalu berpengaruh terhadap minat menabung nasabah tetapi ada faktor pendorong nasabah untuk menabung di bank jateng syariah selain faktor produk di bank syariah. Hasil penelitian ini didukung oleh hasil penelitian yang dilakukan oleh Ainun, Agung, Junaidi (2017) yang menyatakan bahwa produk berpengaruh positif tidak signifikan terhadap minat menabung. Namun Hasil penelitian ini menolak penelitian Hutomo, Chanafi (2016) yang menyatakan bahwa produk memiliki pengaruh positif signifikan terhadap minat menabung.

\section{f. Pengaruh Harga terhadap minat menabung.}

Hasil uji regresi pengaruh harga terhadap minat menabung menyatakan bahwa harga berpengaruh positif tidak signifikan terhadap minat menabung. Menurut Irene, Nobelson, Rosali (2017) harga berpengaruh terhadap minat nasabah menabung di bank jateng syariah, semakin sedikit jumlah biaya yang dikeluarkan nasabah untuk bisa memanfaatkan produk dan jasa bank maka semakin tinggi minat nasabah untuk menabung di bank jateng syariah. Hasil penelitian ini juga didukung oleh hasil penelitian yang dilakukan oleh Mohamad Wildan (2018) yang menyatakan bahwa harga berpengaruh positif tidak signifikan terhadap minat menabung. Namun Hasil penelitian ini menolak penelitian Jonathan Herdioko (2017) yang menyatakan bahwa harga berpengaruh positif dan signifikan terhadap minat menabung. Dalam konteks perbankan harga merupakan sejumlah uang yang dibayarkan oleh nasabah kepada Bank agar bisa memanfaatkan produk atau jasa perbankan.

\section{KESIMPULAN}

Hasil analisis menunjukan bahwa lokasi secara parsial berpengaruh negatif dan tidak signifikan terhadap minat nasabah manabung di Bank Jateng Syariah, pelayananan secara parsial berpengaruh positif signifikan terhadap minat nasabah menabung di Bank Jateng Syariah.,pengetahuan secara parsial berpengaruh positif signifikan terhadap minat nasabah menabung di Bank Jateng Syariah,promosi secara parsial berpengaruh positif tidak signifikan terhadap minat nasabah menabung di bank jateng syariah, produk secara parsial berpengaruh positif tidak signifikan terhadap minat nasabah menabung di Bank Jateng Syariah, harga secara parsial berpengaruh positif tidak signifikan terhadap minat nasabah menabung di Bank Jateng Syariah.

\section{REFERENSI}

Afif, ghafar ramadhan,. Dan Santosa, Budi Suryono. 2017. Analisis Pengaruh Kualitas Produk, Kualitas Pelayanan, dan Citra Merek terhadap Minat Beli Ulang pada Sepatu Nike Running di Semarang melalui Kepuasan Pelanggan sebagai Variabel Intervening. Diponegoro journal of management volume 6, nomor 1, tahun 2017, halaman 1-12 Http://ejournals1.undip.ac.id/index.php/management issn (online): $2337-3806$

Astuti, Pudji,. Dan Umiyati. 2018. Inluence Of Religiosity Towards The Saving Interest At Islamic Banking With The Knowledge Of The People As Moderator Variable (Case Study On The People Of South Tanggerang City). Journal of Islamic Economics and Business

Volume 3, No 1 (2018) ISSN : $2527-$ 3434 (PRINT) - ISSN: 2527-5143 (ONLINE)

Page : $1-16$ 
Andespa, Roni. 2017. Faktor-faktor yang mempengaruhi minat nasabahdalam menabung di bank syariah. Jurnal Lembaga Keuangan dan PerbankanVolume 2, Nomor 1, Januari-Juni 2017

Chatifah, Yuliana Siti. 2018. Peningkatan Minat Menabung di Bank Syariah melalui Program Office Channeling. Journal of Finance and Islamic Banking Vol. 1 No. 1, hal 65.

Damayanti, Sisca. 2017. Pengaruh Pandangan Islam, Pelayanan, dan Keamanan Terhadap Minat Nasabah Untuk Menabung di Bank Syariah Mandiri Cabang X. Jurnal Manajemen dan Pemasaran Jasa.

Dayyan, Muhammad,. Riza, Muhammad, Dan Ridwan, Amalya. 2017. Analisis pemahaman masyarakat mengenai perbankan syariah minat menabung (studi kasus di gampong jawa). Jurnal Ilmiah Mahasiswa (JIM) vol. 1, no 1, tahun 2017.

Dr.Ren-Fang Chao. 2016. The Impact of Brand Image and DiscountedPrice on Purchase Intention in Outlet Mall:Consumer Attitude as Mediator. The Journal of Global Business Management Volume 12* Number 2* October 2016 issue

Ghozali, Imam. 2016. Aplikasi Analisis Muktivariete dengan Program IBM SPSS 21.Edisi 8. Semarang.

Herdioko, Jonathan. 2017. Pengaruh produk dan harga terhadap minat beli konsumen dalam berbelanja produk kopi secara daring: Studi kasus pada situs internet otten coffe. JRMB Volume 12 No 2 , Desember 2017.

Kasmir. 2014. Bank Dan Lembaga keuangan Lainnya. PT Raja Grafindo Persada. Jakarta.

Reshita, Riries Mia., pengaruh promosi, lokasi, dan kualitas pelayanan Terhadap minat menabung nasabah Di bank bni di sidoarjo
Lupiyoadi, Rambat. 2017. Manajemen Pemasaran Jasa berbasis Kompetensi Edisi 3.Salemba Empat. Jakarta

Latief, Abdul. 2018. Analisis Pengaruh Produk, Harga, Lokasi dan Promosi terhadap Minat Beli Konsumen pada Warung Wedang Jahe (Studi Kasus Warung Sido Mampir di Kota Langsa). Jurnalmanajemen dan keuangan, vol.7, no. 1 , mei 2018

Mardiah, Ainun., Putra, Agung Pradana., dan Junaidi. 2017. Peningkatan Minat Masyarakat Menabung di bank syariah (Studi Kasus di Kampung Paya Bedi Aceh Tamiang).Jurnal Ilmiah Mahasiswa Vol 1 No.1, hal 7.

Mawardi, Pengaruh Promosi Tabungan Bank Sumsel Babel Syariah Terhadap Minat Menabung Masyarakat Kota Palembang. Al-Tijary Jurnal Ekonomi dan Bisnis Islam P- ISSN: 2460-9404; E-ISSN: 2460-9412, 2018, Vol. 4, No. 1, Hal. 43-52 doi: http://dx.doi.org/10.21093/at.v4i1.128 2

Muhamad. 2014. Manajemen Dana Bank Syariah. PT Raja Grafindo Persada. Jakarta.

Ortega, Daniel,. Dan Alhifni, Anas. 2017. Pengaruh Media Promosi Perbankan Syariah Terhadap Minat Menabung Masyarakat di Bank Syariah. Jurnal Ekonomi Syariah Vol 5 No 1, hal 89.

Priansa, Donni Juni. 2017 . Perilaku Konsumen Dalam Persaingan Bisnis Kontemporer.Bandung: Alfabeta.

Pohos, Tika Secylia,. Dotulong, Lucky,. Dan Trang, Irvan. 2017. Kualitas pelayanan dan bauran pemasaran pengaruhnya terhadap niat membeli di indomaret wangurer bitung. Jurnal EMBA Vol.5 No.2 Juni 2017, Hal.2394-2400 ISSN 2303-1174.

Rusdianto, Hutomo,. Dan Chanafi, Ibrahim. 2016. Pengaruh Produk Bank Syariah Terhadap Minat Menabung Dengan Persepsi Masyarakat Sebagai Variabel 
Moderating di Pati. Jurnal Ekonomi Syariah Vol 4 No 1, hal 44.

Sugiyono. 2015. Metode Penelitian Manajemen. Alfabeta. Bandung.

Sujarweni, Wiratna. V .2015 .Metodologi Penelitian Bisnis \& Ekonomi.Pustaka Baru Pres. Yogyakarta.

Suryani, Tatik. 2017. Manajemen Pemasaran Strategik Bank di Era Global. Jakarta.

Syaribulan.2018. Bauran Pemasaran Dan pengaruhnya Terhadap Minat Nasabah Untuk Menabung di Tabungan Tampan, Bank Sulselbar.Jurnal Manajemen, ide, Inspirasi Vol 5 No 1.

https://www.ojk.go.id/id/berita-dan

kegiatan/siaranpers/Documents/Pages/Siaran-PersOJK-Indeks-Literasi-dan-Inklusi-

Keuangan

Meningkat/17.01.23\%20Tayangan\%2

0\%20Presscon\%20\%20nett.compresse d.pdf. Diakses pada tanggal 2 Oktober 2018

www.ojk.go.id. Diakses pada tanggal 2 Oktober 2018

www.bi.go.id. Diakses pada tanggal 3 Oktober 2018 